
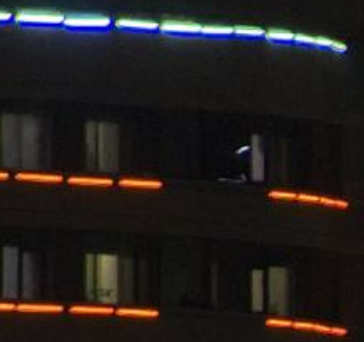

$y$<smiles>c1ccccc1</smiles>
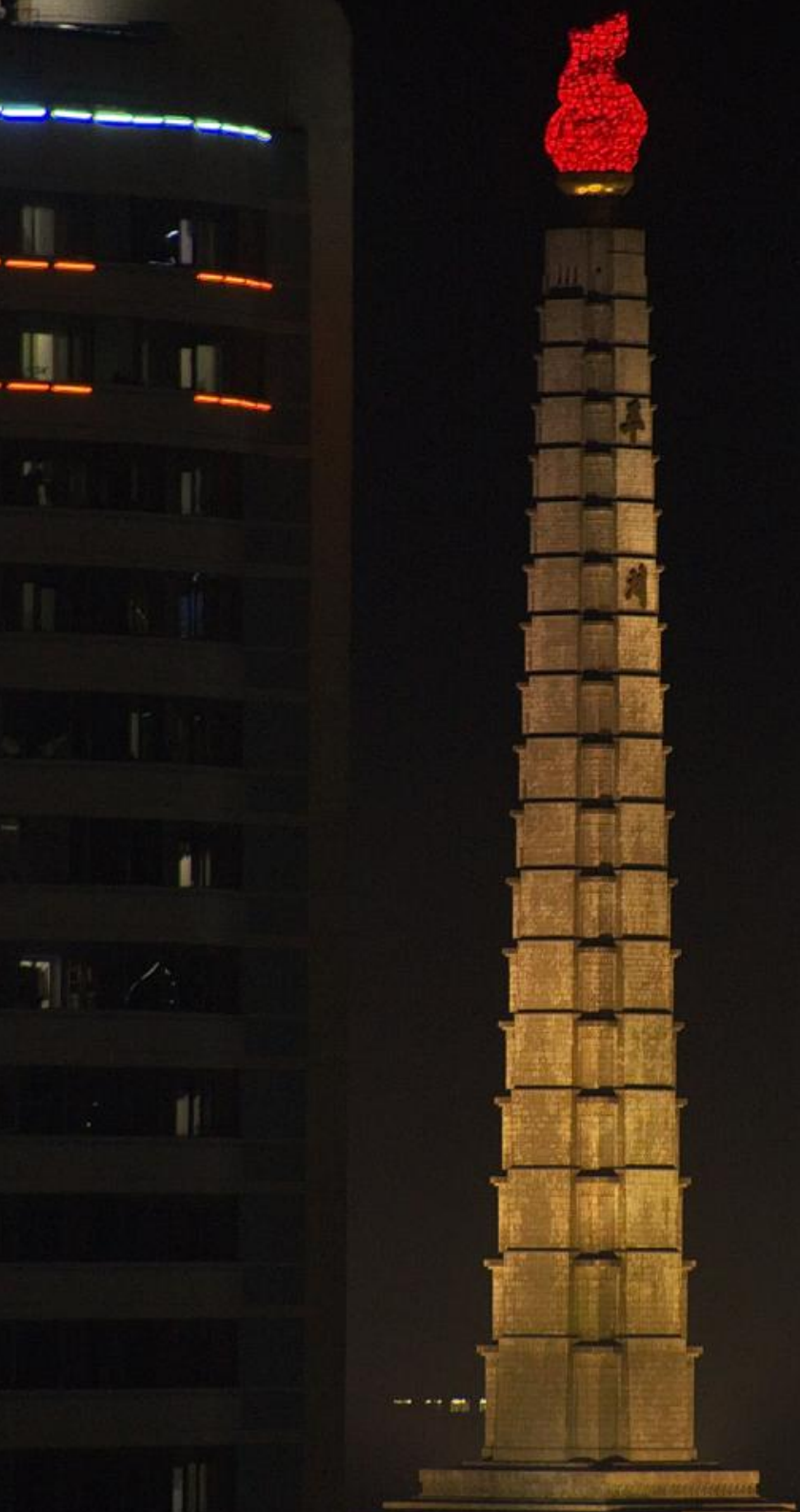

The Juche Tower in Pyongyang.

Photo by Uwe Brodrecht, used under CC BY-SA.2.0 


\section{COMMENTARY: "WE MUST BE READY FOR REVENGE": THE REAL VALUE OF CHILDHOOD IN NORTH KOREA}

\section{By Robert Huish}

\section{Associate Professor,}

International Development

Studies, Dalhousie University

The Korean Children's Union is not designed to nurture nor to inspire its members through friendship, camaraderie, or duty. It is meant to belittle, to intimidate, and to instill the belief that the supreme leader is all powerful. It rigorously instructs children that to be an individual is meaningless. No child is unique. Each one is just like the other. Replaceable, disposable, and ultimately? Worthless.

Based on the testimony of numerous defectors, we know that North Korean children are told by the government to love the supreme leader more than their own parents. Mom and dad may be responsible for them day to day, but ultimately it is the leader who provides for them in every way. Sound cultish? It is.

Juche, or "self reliance", is North Korea's official ideology meant to drive the nation towards true socialism. It is a deranged and maniacal cult of personality that convinces people not to think for themselves, but to think through the leader. 
It begins with nursery rhymes. There are two distinct kinds. The first gives fawning praise and boisterous credence to Kim Il Sung, the eternal leader of North Korea, along with his direct descendants Kim Jong Il, and Kim Jong Un. The second set of children's songs are chalked full of lyrics about killing "Japanese dogs" and dismembering "American bastards". Children are told that those who question the leader, or those who show dissent, are "mushrooms that grow in human shit". In their earliest days of song and speech, North Korean children learn to worship one man, prepare for revenge against the country's enemies, and all through a barrage of intimidation and vulgarity.

This is the experience for the "elite class" - those lucky enough to live in the relative comfort of Pyongyang. For those deemed "wavering" or "hostile" by the DPRK's Songbun caste system, a feudal system categorizing the population based on political loyalty, the living conditions worsen, while the psychological abuse intensifies. While still forced to show audacious affection to the Dear Leader, teachers and police remind children in the wavering class that their only value in life will be service to the leader through tiring work.

For those deemed "hostile", childhood turns to horror. Food is minimal, and malnutrition rampant. Stories emerge of feral children near the Chinese border who, abandoned by their parents, live a roaming existence in pacts in search of food and warmth. One child was found crossing the Chinese border in the middle of winter with terrible burns to his bare feet. Trying to stay warm, he knocked over a kerosene lamp that ignited his shoes.

In political prisons, protein is so scarce that rats and lizards are highly regarded commodities. In the political labour camps North Korean children can be born into captivity. Defector testimony presented to the United Nations Commission of Inquiry into Human Rights Abuses in North Korea include stories of male and female political prisoners, some with no previous relations, be forced into conjugal visits while in captivity. If a child comes of this, that child will live a life starved, and physically worked to absolute exhaustion. The Songbun system demands three generations of punishment for those hostile to the regime. Children born into North Korean prison camps are often there for the political crimes of their parents or grandparents.

Since the tightening of sanctions against the Kim Regime in 2017, North Korea has embarked on a feel-good campaign of diplomacy. Kim Jong smiles and shakes hands with leaders from South Korea, China, Russia, the United States, and he has even invited Pope Francis to visit.

Peter Steele's article reminds us that far from the photogenic summits, papal invitations, and the high-level diplomacy remains a horrifying reality for children in North Korea. Steele writes, "the life of children in North Korea can take many different forms, but all share a legacy of systematic abuse... which infringe the rights of the child". 
The key word here is "systemic". North Korea raises generation after generation through a cult of personality that goes beyond violating UN conventions and international edicts. North Korea robs its own children of humanity. It is not done by accident, or by consequence of a catastrophic event. Dehumanizing compatriots, including children, is a carefully scripted North Korean policy. Bureaucrats engineer it, soldiers implement it, and Kim Jong Un repeats it with impunity.

It is almost assumed that every nation has genuine concern for the well-being of its children. Steele's article shines a much needed light on the everyday horrors of North Korea, and the absurdity of Songbun. It illuminates just how obscene it is for Washington, Seoul, Beijing and Moscow to want to dismantle ballistic weapons systems in the DPRK, while remaining mute on Mr. Kim's astounding abuses to human security.

By all rights childhood in North Korea is a governed experience to weaponize youth through conformity, intimidation and degradation. It is all to keep a cult of personality in power. If the international community is serious about peace in the Korean peninsula, The Korean Children's Union, and other tenets of the Songbun system, must be dismantled just like any other weapons system.

Robert Huish is Associate Professor in International Development Studies at Dalhousie University. Dr. Huish's research covers a wide range of topics such as global health, social justice and human security in North Korea. Author of two books, and numerous articles, his current research looks at human rights abuses, security issues, and the refugee crisis within North Korea. Dr. Huish's articles in the Journals, "Asia Policy" and "Canadian Naval Review" expose a shadowy network of shell companies, fraudulent insurance companies and offshore capital that allows North Korea to circumvent international sanctions, and to perpetuate its human rights abuses. 